\title{
Multivariate Analysis of Accidents in Children Under 15 in Algeria (2012-MICS4)
}

\author{
Kouaouci Alia, Khaldi Abdelkamela
}

\begin{abstract}
Usually, data on road traffic accidents in Algeria are not available to researchers. Fortunately, MICS4-the Multiple Indicator Cluster Survey conducted by UNICEF during 2012-2013 has introduced a module on accidents among children less than 15 years. In Algeria, the MICS4 survey targeted a sample of 28,000 households distributed over the national territory. These are the main results of polynomial logistic regression: Children in the richest quintile ( $\mathrm{B}=.562, p<.05)$, are much less exposed than children in the poorest quintile. The odd ratio is 1.75 . Compared to children aged 12 to 14 , the younger children of $0-2$ years ( $\mathrm{B}=-1.059, p<.05$ ), are three times less exposed (odd ratio $=.347$ ) to road traffic accidents; and children of 9-11 years $(\mathrm{B}=.520, p<.05)$, are most exposed with an odd ratio of 1.68. For territorial planning areas, with the South being taken as a reference category, the risk of traffic accidents for a child is the lowest in the West Highlanders $(\mathrm{B}=-1.257, p<.05)$, followed by the North Center ( $\mathrm{B}=-1.163, p<.05)$, the East Highlands ( $\mathrm{B}=-1.053, p<.05)$, the Northwest $(\mathrm{B}=-1.034, p<.05)$, and the Northeast $(\mathrm{B}=-.805, p<.05)$. Odd ratio values are respectively $.29, .313, .349, .356$, and .447 .
\end{abstract}

Keywords

Road traffic accidents, Algeria, logistic regression, wealth quintile

Data on road traffic accidents in Algeria are not available to researchers, usually. The only available data consist of already tabulated data by age, sex, region, wilayates, etc. Of course with this type of data, conducting multivariate analysis is very difficult. Fortunately, MICS4 - the Multiple Indicator Cluster Survey conducted by UNICEF during 2012-2013 has introduced a module on accidents among children less than 15 years.

Besides, the only alternate source available, a government center devoted to road traffic accidents released statistics covering the period 1991-2002 that give an idea of the extent of accidents in Algeria with their share of victims either injured or killed. Figure 1 displays the various issues following accidents as well as fatality rates per 100,000 . The period covers largely the black decade and for this reason, it can be seen that in 1994 and 1995, at the peak of violence, accidents in Algeria declined, no doubt because only essential trips were made in order to avoid fake check points and other imponderables.

These statistics are provided by the Tahina report on causes of death. The traffic accident is the leading cause of intentional $(61.6 \%)$ and post-traumatic $(40.2 \%)$ deaths. It accounts for $4.3 \%$ of total deaths and comes in the 6th place after other cardiovascular diseases (8.6\%), cerebrovascular diseases $(7.5 \%)$, hypertensive heart disease $(6.6 \%)$, other perinatal conditions (6.5\%), and low birth weight (4.4\%).

\section{aUniversity of Batna-1, Algeria}

\section{Correspondent Author:}

Kouaouci Ali, University of Batna-1, 1 impasse Benbattouche, Barika, wilaya Batna, Algeria 
The young male adult is the first victim. Female deaths, which are fewer in number, occur mainly at extreme ages. Among the 5-14 years old, the traffic accident is the leading cause of death $(21.2 \%)$ preceding the group of other cardiovascular diseases (7.4\%).

The fact that Algerians accessed recently to various credit schemes caused a rapid motorization with increased road traffic accidents risks. In 2002, we had about 40,000 annual accidents with about 4,000 deaths and 57,000 injuries.

\section{DATA AND METHODS}

MICS4 is the only available Algerian source that included the accident module for children under 15 years of age. Its objective is to inform the progress made towards the Millennium Development Goals Objectives, as well as national development goals. In Algeria, the MICS4 survey targeted a sample of 28,000 households distributed over the national territory.

MICS4 gives a rare opportunity to analyze these data, while ensuring their quality. Unfortunately, the quality of the MICS4 data needs to be examined seriously, as will be seen. A crucial variable, such as the wealth score from which wealth quintiles were calculated, seemed to be a priority variable in the analysis of accidents occurring among children under the age of 15 , especially that exposure to traffic accidents certainly relates to the socio-economic level of the household. However, curiously, a negative score is assigned to $43.2 \%$ of the sample. In the MICS4 report, each household was assigned a wealth score based on various items possessed by members of the household. The household population of the survey was then ranked according to the wealth score of the household in which it lives and was finally divided into five equal parts (quintiles) ranging from the lowest (the poorest) to the highest (the richest). The wealth index does not provide information on absolute poverty, current levels of income or expenditure. It is only based on items possessed without any explanation on the score construction.

However, quite strangely, the report of almost 400 pages does not include any list of references or bibliography. The work of Rutstein and Johnson (2004) cited by the authors discourages the use of negative scores, while in Algeria, the choice was made to go precisely with negative scores.

As a result, the authors noticed that these biased quintiles are not giving a clear-cut pattern when they use them as an explanatory variable. The authors chose to work only on the positive scores to see if the quintiles calculated on this basis would be more discriminating than the quintiles proposed by MICS4. This crucial variable was not very decisive although it was extensively used.

In several attempts, the quintile variable proved incapable of restoring differences that could logically be foreseen. This prompts to question the very construction of this index by the authors of MICS4-Algeria. The authors therefore called this variable quintilecorr to distinguish it from quintile but more work would be needed to solve this problem.

The authors will conduct bivariate and multivariate analyses in order to identify the most determinants variables standing behind road traffic accidents among children less than 15 years of age.

\section{RESULTS}

From these data, the authors can compare the estimates based on the quintiles proposed by MICS4 and those based on quintilescorr. It can be seen that while in general the figures are of the same order of magnitude, the rank of the modalities may change, as for example for traffic accidents. Thus, the second quintile presents the lowest risk of accidents when quintiles are used, and it is the richest quintile that has this characteristic if quintilecorr is used. The authors will therefore use quintilecorr for the rest of this 


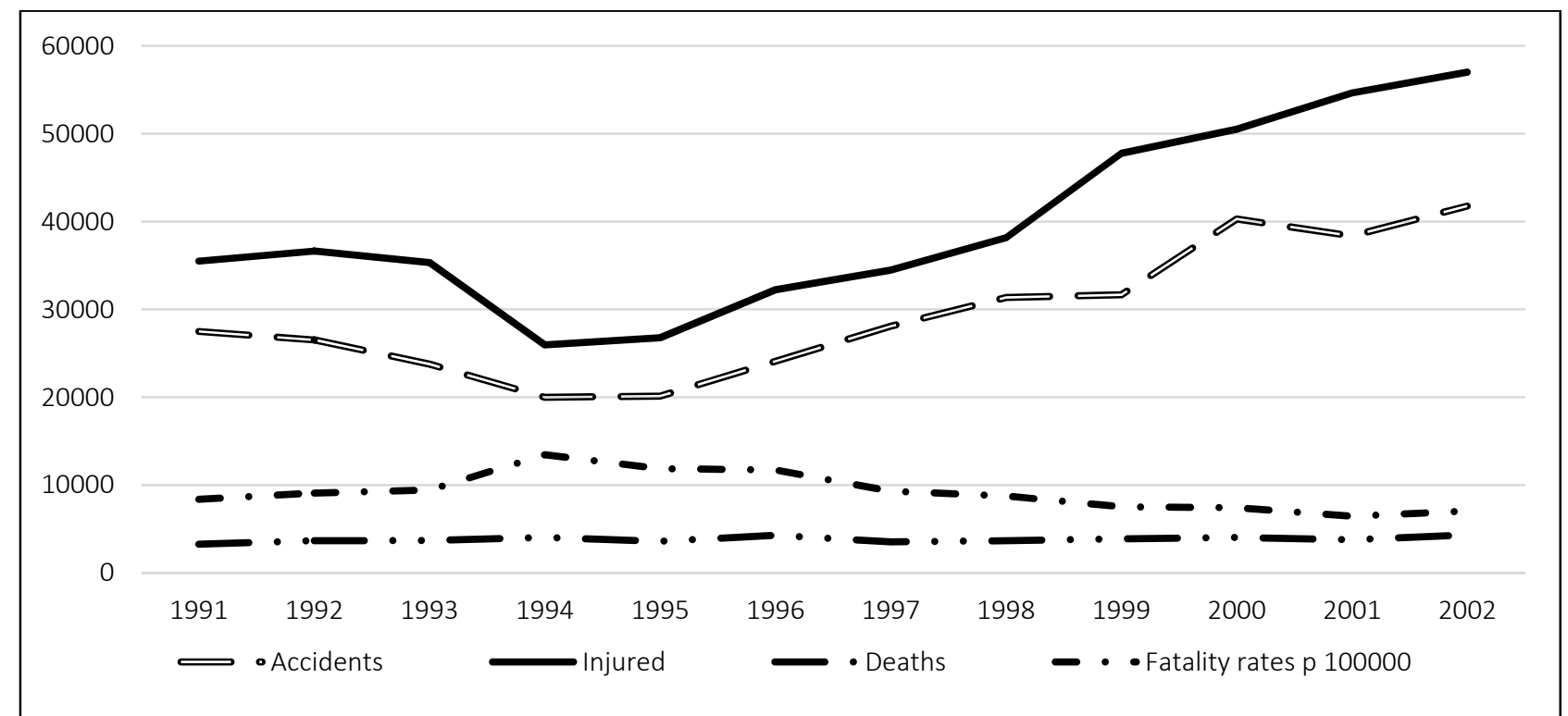

Figure 1. Number of Road Traffic Accidents, Casualties, Injured, and Fatality Rates per 100,000, Algeria 1991-2002.

analysis and invite MICS4 officials to conduct a review of their database currently made available on the UNICEF website. In particular, the wealth quintile variable has been systematically used in all tables produced on chronic diseases, handicaps, etc.

In MICS4, the mother or guardian is asked about the accident occurring to children under 15 .

(1) Type of accident;

(2) Age at which the accident occurred;

(3) Origin of the accident (fall, fight, fire, traffic accident, etc.);

(4) Location of the accident (at home, at school, on the street, other);

(5) Whether the child victim of an accident has been taken to a health facility;

(6) In case the child was simply treated at home, ask the reason.

The report of MICS4-Algeria concludes that according to the declarations of the mothers, $8 \%$ of child of less than 15 years, have suffered a serious accident at least once during their lifetime.
The survey also reveals that accidents are relatively more frequent among children living in urban areas compared with those living in rural areas (9\% versus 6\%). The accidents appear to be relatively higher in the EPT (Territorial Planning Area) grouping the wilayas of the South of the country (11\%) and in the EPT North Center with $9 \%$ of children under 15 years of age. The EPT that recorded the least number of accidents are the EPTs of the Highlanders West and Highlanders Center with a prevalence of $5 \%$ each. More than two-thirds of children (67\%) accident victims are aged between 6 and 14 years.

The following remarks are based on Table 1:

(1) Traffic accidents are more likely to affect girls than boys ( $13 \%$ and $12 \%)$;

(2) Hospital is the first choice for care;

(3) The poorest quintile is most at risk of traffic accidents when using quintile estimated by MICS4, while the third quintile is the most at risk if using the positive-scores quintile. 
Table 1. Bivariate Analysis of Type of Accidents and Some Socio-demographic Variables

\begin{tabular}{|c|c|c|c|c|c|c|c|c|c|}
\hline & & Fall & Fire & Fight & Traffic & $\begin{array}{l}\text { Parental } \\
\text { punishment }\end{array}$ & Other & Total & $\mathrm{N}$ \\
\hline \multirow{2}{*}{ Sex } & Male & 64.9 & 5.4 & 4.7 & 12.1 & 6 & 12.4 & 100 & 1,518 \\
\hline & Female & 61.9 & 4.3 & 3.0 & 13.5 & 1.4 & 15.8 & 100 & 942 \\
\hline \multirow{4}{*}{ Type of accident } & Burn & 29.5 & 25.4 & 1.9 & 1.9 & 1.8 & 39.5 & 100 & 395 \\
\hline & Injuries & 70.5 & 1.5 & 5.1 & 15.0 & .8 & 7.1 & 100 & 1,073 \\
\hline & Fracture/sprain & 77.4 & .7 & 3.7 & 12.6 & .8 & 4.9 & 100 & 808 \\
\hline & Other & 37.8 & .3 & 3.6 & 22.7 & .1 & 35.7 & 100 & 181 \\
\hline \multirow{4}{*}{$\begin{array}{l}\text { Location of the } \\
\text { accident }\end{array}$} & Home & 69.4 & 7.6 & 2.4 & 1.2 & 1.3 & 18.2 & 100 & 1,328 \\
\hline & School & 78.2 & 4.4 & 9.2 & 2.3 & .0 & 5.7 & 100 & 128 \\
\hline & Street & 52.7 & .8 & 6.1 & 33.0 & .5 & 6.8 & 100 & 868 \\
\hline & Other & 65.8 & 7.1 & 2.1 & 4.0 & .0 & 20.9 & 100 & 136 \\
\hline \multirow{5}{*}{ Health facility } & Hospital & 64.2 & 4.3 & 4.0 & 14.4 & .9 & 12.2 & 100 & 1,955 \\
\hline & Polyclinic/treatment room & 62.3 & 10.2 & 4.8 & 4.7 & .9 & 17.0 & 100 & 258 \\
\hline & Private doctor & 63.5 & 4.2 & 1.1 & 5.4 & 3.6 & 22.1 & 100 & 60 \\
\hline & Treated at home & 65.9 & 5.4 & 1.5 & 7.6 & .0 & 19.4 & 100 & 142 \\
\hline & Other & 43.9 & 5.9 & 7.3 & 9.3 & .0 & 32.9 & 100 & 37 \\
\hline \multirow{2}{*}{$\begin{array}{l}\text { Reason not using } \\
\text { health care }\end{array}$} & Useless & 61.5 & .5 & 4.0 & 10.7 & .0 & 22.8 & 100 & 82 \\
\hline & Had past experience & 56.3 & 10.5 & 1.2 & 2.0 & .0 & 29.5 & 100 & 41 \\
\hline \multirow{5}{*}{ Wealth quintiles } & Poorest $20 \%$ & 58.4 & 7.6 & 3.1 & 15.1 & .7 & 15.0 & 100 & 401 \\
\hline & Second $20 \%$ poorest & 66.5 & 3.9 & 5.3 & 8.5 & .5 & 15.4 & 100 & 491 \\
\hline & Third & 64.1 & 3.9 & 4.8 & 13.9 & .8 & 12.5 & 100 & 554 \\
\hline & Fourth & 60.8 & 5.3 & 4.2 & 14.5 & 1.4 & 13.9 & 100 & 539 \\
\hline & Richest 20\% & 68.3 & 4.8 & 2.4 & 11.4 & 1.0 & 12.0 & 100 & 475 \\
\hline \multirow{5}{*}{ Quintilecorr } & Poorest $20 \%$ & 63.0 & 5.8 & 5.5 & 14.8 & 1.2 & 9.6 & 100 & 344 \\
\hline & Second $20 \%$ poorest & 64.3 & 3.2 & 2.9 & 12.3 & .5 & 16.9 & 100 & 248 \\
\hline & Third & 63.9 & 5.6 & 4.2 & 15.3 & 1.0 & 10.0 & 100 & 323 \\
\hline & Fourth & 62.0 & 3.4 & 3.9 & 14.5 & 1.9 & 14.2 & 100 & 305 \\
\hline & Richest $20 \%$ & 69.4 & 6.1 & 1.3 & 9.5 & .7 & 13.0 & 100 & 262 \\
\hline
\end{tabular}

Based on the adjusted wealth quintiles, the authors can formulate the following observations:

(1) Children in the richest quintile are more likely to fall than those in the poorest quintile $(69.4 \%$ versus $63 \%)$;

(2) For fires, MICS4 poorest quintile is the most exposed while using quintilecorr, the authors found that the children from the richest quintile are the most exposed as can be seen in Figure 2;

(3) On the other hand, fights are more frequent among children in the poorest quintile $(5.5 \%$ versus $1.3 \%)$;
(4) Just as traffic accidents are one and a half times more frequent among children in the poorest quintile (14.8\% versus $9.5 \%)$;

(5) As well as parental punishment (1.2\% versus $0.7 \%$ ). It should be noted, however, that children in the fourth quintile seem to be the most prone to parental punishment (1.9\%).

The authors use hereafter results from the logistic regression as presented in Table 2 .

Compared to the South, the risks of fires involving children under the age of 15 are six times higher in the Central Highlands $(\mathrm{B}=1.837, p<.05)$ and almost 


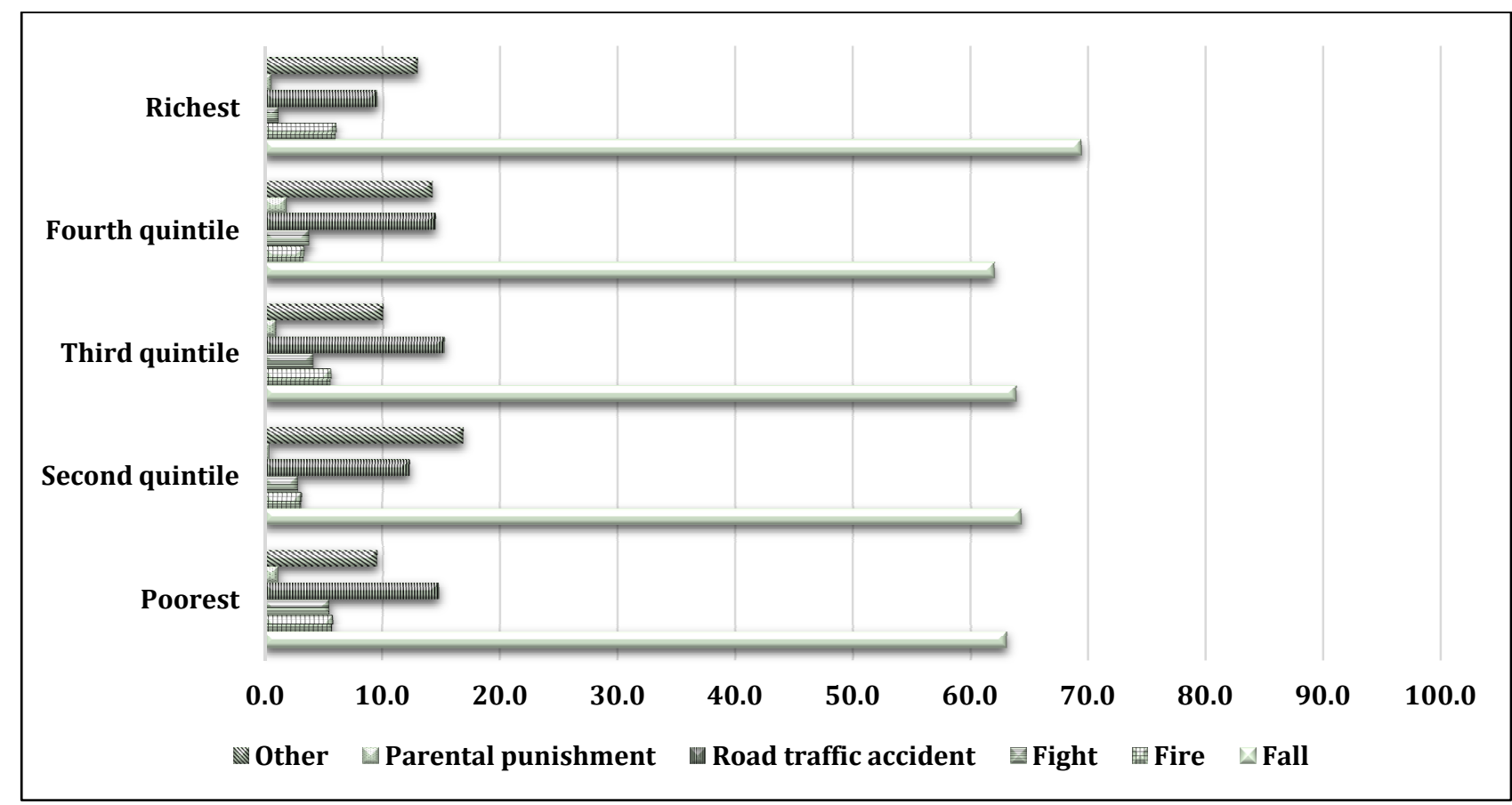

Figure 2. Type of Accident by Wealth Quintile (Corrected).

Table 2. Polynomial Logistic Regression of Occurrence of Different Types of Accidents by Sex, Age, Wealth Quintile Corrected, Residence Stratum, and EPT (Territorial Planning Area)

\begin{tabular}{|c|c|c|c|c|c|c|c|c|c|}
\hline \multicolumn{10}{|c|}{ Fire } \\
\hline & & \multirow[t]{2}{*}{ B } & \multirow[t]{2}{*}{ SE } & \multirow[t]{2}{*}{ Wald } & \multirow[t]{2}{*}{$\mathrm{df}$} & \multirow[t]{2}{*}{ Sig. } & \multirow[t]{2}{*}{$\operatorname{Exp}(B)$} & \multicolumn{2}{|c|}{$\begin{array}{l}95 \% \\
\text { confidence } \\
\text { interval for } \\
\text { Exp(B) }\end{array}$} \\
\hline & & & & & & & & $\begin{array}{l}\text { Lower } \\
\text { bound }\end{array}$ & $\begin{array}{l}\text { Upper } \\
\text { bound }\end{array}$ \\
\hline \multirow{6}{*}{ Quintiles } & Intercept & -3.602 & .755 & 22.771 & 1 & .000 & & & \\
\hline & (quintilecorr $=1.00$ ) & -.010 & .365 & .001 & 1 & .978 & .990 & .484 & 2.024 \\
\hline & (quintilecorr $=2.00$ ) & -.601 & .460 & 1.707 & 1 & .191 & .548 & .222 & 1.351 \\
\hline & (quintilecorr $=3.00$ ) & -.059 & .364 & .026 & 1 & .871 & .943 & .462 & 1.925 \\
\hline & (quintilecorr $=4.00$ ) & -.515 & .417 & 1.526 & 1 & .217 & .597 & .264 & 1.353 \\
\hline & (quintilecorr $=5.00$ ) & $0 \mathrm{~b}$ & & & 0 & & & & \\
\hline \multirow{5}{*}{ Age } & $(0-2$ yrs $)$ & -.293 & .517 & .321 & 1 & .571 & .746 & .271 & 2.055 \\
\hline & (3-5 yrs) & .334 & .364 & .841 & 1 & .359 & 1.396 & .684 & 2.850 \\
\hline & (6-8 yrs) & .435 & .341 & 1.630 & 1 & .202 & 1.546 & .792 & 3.015 \\
\hline & (9-11 yrs) & -.064 & .397 & .026 & 1 & .872 & .938 & .431 & 2.044 \\
\hline & (12-14 yrs) & $0 \mathrm{~b}$ & & & 0 & & & & \\
\hline \multirow{2}{*}{ Sex } & (Male) & .207 & .264 & .614 & 1 & .433 & 1.230 & .733 & 2.064 \\
\hline & (Female) & $0 \mathrm{~b}$ & & & 0 & & & & \\
\hline \multirow{2}{*}{ Residence } & Urban & .114 & .355 & .104 & 1 & .747 & 1.121 & .560 & 2.246 \\
\hline & Rural & $0 \mathrm{~b}$ & & & 0 & & & & \\
\hline \multirow{7}{*}{ EPT } & North-Centre & .739 & .598 & 1.526 & 1 & .217 & 2.095 & .648 & 6.768 \\
\hline & North-East & .763 & .693 & 1.210 & 1 & .271 & 2.144 & .551 & 8.342 \\
\hline & North-West & .324 & .735 & .195 & 1 & .659 & 1.383 & .328 & 5.836 \\
\hline & Highlanders. Centre & 1.837 & .719 & 6.529 & 1 & .011 & 6.277 & 1.534 & 25.685 \\
\hline & Highlanders. East & 1.312 & .621 & 4.467 & 1 & .035 & 3.715 & 1.100 & 12.544 \\
\hline & Highlanders. West & .691 & .897 & .593 & 1 & .441 & 1.995 & .344 & 11.580 \\
\hline & South & $0 \mathrm{~b}$ & & & 0 & & & & \\
\hline
\end{tabular}


Table 2 to be continued

\begin{tabular}{|c|c|c|c|c|c|c|c|c|c|}
\hline \multicolumn{10}{|c|}{ Fight } \\
\hline & & \multirow[t]{2}{*}{ B } & \multirow[t]{2}{*}{ SE } & \multirow[t]{2}{*}{ Wald } & \multirow[t]{2}{*}{ df } & \multirow[t]{2}{*}{ Sig. } & \multirow[t]{2}{*}{$\operatorname{Exp}(B)$} & \multicolumn{2}{|c|}{$\begin{array}{l}95 \% \\
\text { confidence } \\
\text { interval for } \\
\text { Exp(B) }\end{array}$} \\
\hline & & & & & & & & $\begin{array}{l}\text { Lower } \\
\text { bound }\end{array}$ & $\begin{array}{l}\text { Upper } \\
\text { bound }\end{array}$ \\
\hline \multirow{8}{*}{ Quintiles } & Intercept & -4.529 & .854 & 28.141 & 1 & .000 & & & \\
\hline & (quintilecorr $=1.00$ ) & 1.678 & .610 & 7.558 & 1 & .006 & 5.356 & 1.619 & 17.720 \\
\hline & (quintilecorr $=2.00$ ) & .970 & .682 & 2.024 & 1 & .155 & 2.637 & .693 & 10.033 \\
\hline & (quintilecorr $=3.00$ ) & 1.371 & .625 & 4.809 & 1 & .028 & 3.937 & 1.157 & 13.403 \\
\hline & (quintilecorr $=4.00$ ) & 1.257 & .632 & 3.955 & 1 & .047 & 3.516 & 1.018 & 12.138 \\
\hline & (quintilecorr $=5.00$ ) & $0 \mathrm{~b}$ & & & 0 & & & & \\
\hline & $(0-2$ yrs $)$ & .094 & .469 & .040 & 1 & .841 & 1.099 & .438 & 2.756 \\
\hline & (3-5 yrs) & -.425 & .452 & .885 & 1 & .347 & .654 & .270 & 1.585 \\
\hline \multirow[t]{3}{*}{ Age } & (6-8 yrs) & -.315 & .420 & .565 & 1 & .452 & .729 & .320 & 1.661 \\
\hline & (9-11 yrs) & .182 & .383 & .226 & 1 & .634 & 1.200 & .566 & 2.541 \\
\hline & (12-14 yrs) & $0 \mathrm{~b}$ & & & 0 & & & & \\
\hline \multirow{2}{*}{ Sex } & (Male) & .640 & .324 & 3.907 & 1 & .048 & 1.897 & 1.005 & 3.580 \\
\hline & (Female) & $0 \mathrm{~b}$ & & & 0 & & & & \\
\hline \multirow{2}{*}{ Residence } & Urban & .168 & .395 & .182 & 1 & .670 & 1.183 & .546 & 2.566 \\
\hline & Rural & $0 \mathrm{~b}$ & & & 0 & & & & \\
\hline \multirow{7}{*}{ EPT } & North-Centre & -.171 & .477 & .128 & 1 & .720 & .843 & .331 & 2.147 \\
\hline & North-East & .405 & .555 & .534 & 1 & .465 & 1.500 & .506 & 4.449 \\
\hline & North-West & -.017 & .605 & .001 & 1 & .978 & .983 & .300 & 3.219 \\
\hline & Highlanders. Centre & -.111 & .857 & .017 & 1 & .897 & .895 & .167 & 4.800 \\
\hline & Highlanders. East & -.032 & .547 & .003 & 1 & .954 & .969 & .331 & 2.832 \\
\hline & Highlanders. West & -.477 & .965 & .244 & 1 & .621 & .621 & .094 & 4.114 \\
\hline & South & $0 \mathrm{~b}$ & & & 0 & & & & \\
\hline \multicolumn{10}{|c|}{ Road traffic accident } \\
\hline & & $\mathrm{B}$ & SE & Wald & $\mathrm{df}$ & Sig. & $\operatorname{Exp}(B)$ & $\begin{array}{l}95 \% \\
\text { confidence } \\
\text { interval for } \\
\text { Exp(B) }\end{array}$ & \\
\hline & & & & & & & & $\begin{array}{l}\text { Lower } \\
\text { bound }\end{array}$ & $\begin{array}{l}\text { Upper } \\
\text { bound }\end{array}$ \\
\hline \multirow{6}{*}{ Quintiles } & Intercept & -1.412 & .394 & 12.840 & 1 & .000 & & & \\
\hline & (quintilecorr $=1.00$ ) & .562 & .273 & 4.219 & 1 & .040 & 1.754 & 1.026 & 2.997 \\
\hline & (quintilecorr $=2.00$ ) & .247 & .301 & .676 & 1 & .411 & 1.281 & .710 & 2.310 \\
\hline & (quintilecorr $=3.00$ ) & .583 & .272 & 4.594 & 1 & .032 & 1.792 & 1.051 & 3.055 \\
\hline & (quintilecorr $=4.00$ ) & .484 & .276 & 3.078 & 1 & .079 & 1.622 & .945 & 2.784 \\
\hline & (quintilecorr $=5.00$ ) & $0 \mathrm{~b}$ & & & 0 & & & & \\
\hline \multirow[t]{5}{*}{ Age } & $(0-2$ yrs $)$ & -1.059 & .403 & 6.907 & 1 & .009 & .347 & .157 & .764 \\
\hline & (3-5 yrs) & -.272 & .250 & 1.179 & 1 & .278 & .762 & .467 & 1.244 \\
\hline & (6-8 yrs) & -.123 & .233 & .276 & 1 & .599 & .885 & .560 & 1.397 \\
\hline & (9-11 yrs) & .520 & .211 & 6.068 & 1 & .014 & 1.681 & 1.112 & 2.542 \\
\hline & (12-14 yrs) & $0 \mathrm{~b}$ & & & 0 & & & & \\
\hline \multirow[t]{2}{*}{ Sex } & (Male) & -.129 & .162 & .631 & 1 & .427 & .879 & .639 & 1.208 \\
\hline & (Female) & $0 \mathrm{~b}$ & & & 0 & & & & \\
\hline \multirow[t]{3}{*}{ Residence } & Urban & .471 & .249 & 3.585 & 1 & .058 & 1.602 & .984 & 2.609 \\
\hline & Rural & $0 \mathrm{~b}$ & & & 0 & & & & \\
\hline & North-Centre & -1.163 & .225 & 26.791 & 1 & .000 & .313 & .201 & .485 \\
\hline \multirow{6}{*}{ EPT } & North-East & -.805 & .300 & 7.181 & 1 & .007 & .447 & .248 & .806 \\
\hline & North-West & -1.034 & .307 & 11.323 & 1 & .001 & .356 & .195 & .649 \\
\hline & Highlanders. Centre & -.608 & .425 & 2.049 & 1 & .152 & .544 & .237 & 1.252 \\
\hline & Highlanders. East & -1.053 & .278 & 14.313 & 1 & .000 & .349 & .202 & .602 \\
\hline & Highlanders. West & -1.237 & .491 & 6.340 & 1 & .012 & .290 & .111 & .760 \\
\hline & South & $0 \mathrm{~b}$ & & & 0 & & & & \\
\hline
\end{tabular}


Table 2 to be continued

\begin{tabular}{|c|c|c|c|c|c|c|c|c|c|}
\hline \multicolumn{10}{|c|}{ Parental punishment } \\
\hline & & \multirow[t]{2}{*}{ B } & \multirow[t]{2}{*}{$\mathrm{SE}$} & \multirow[t]{2}{*}{ Wald } & \multirow[t]{2}{*}{ df } & \multirow[t]{2}{*}{ Sig. } & \multirow[t]{2}{*}{$\operatorname{Exp}(B)$} & \multicolumn{2}{|c|}{$\begin{array}{l}95 \% \text { confidence } \\
\text { interval for } \operatorname{Exp}(B)\end{array}$} \\
\hline & & & & & & & & $\begin{array}{l}\text { Lower } \\
\text { bound }\end{array}$ & $\begin{array}{l}\text { Upper } \\
\text { bound }\end{array}$ \\
\hline & Intercept & -23.735 & 1.572 & 228.066 & 1 & .000 & & .266 & \\
\hline \multirow{5}{*}{ Quintiles } & (quintilecorr $=1.00$ ) & .517 & .940 & .302 & 1 & .582 & 1.676 & .052 & 10.573 \\
\hline & (quintilecorr $=2.00$ ) & -.530 & 1.237 & .184 & 1 & .668 & .588 & .184 & 6.643 \\
\hline & (quintilecorr $=3.00$ ) & .194 & .963 & .041 & 1 & .840 & 1.214 & .541 & 8.010 \\
\hline & (quintilecorr $=4.00$ ) & 1.146 & .898 & 1.627 & 1 & .202 & 3.144 & .948 & 18.282 \\
\hline & (quintilecorr $=5.00$ ) & $0 \mathrm{~b}$ & & & 0 & & & & \\
\hline \multirow[t]{5}{*}{ Age } & $(0-2$ yrs $)$ & 2.036 & 1.066 & 3.646 & 1 & .056 & 7.657 & .434 & 61.876 \\
\hline & (3-5 yrs) & 1.249 & 1.063 & 1.379 & 1 & .240 & 3.486 & .691 & 28.013 \\
\hline & (6-8 yrs) & 1.626 & 1.018 & 2.548 & 1 & .110 & 5.082 & .384 & 37.401 \\
\hline & (9-11 yrs) & 1.123 & 1.061 & 1.120 & 1 & .290 & 3.073 & .123 & 24.576 \\
\hline & (12-14 yrs) & $0 \mathrm{~b}$ & & & 0 & & & & \\
\hline \multirow[t]{2}{*}{ Sex } & (Male) & -1.048 & .535 & 3.836 & 1 & .050 & .350 & .203 & 1.001 \\
\hline & (Female) & $0 \mathrm{~b}$ & & & 0 & & & & \\
\hline \multirow[t]{2}{*}{ Residence } & Urban & .072 & .849 & .007 & 1 & .933 & 1.074 & .266 & 5.676 \\
\hline & Rural & $0 \mathrm{~b}$ & & & 0 & & & .052 & \\
\hline
\end{tabular}

Note: The reference category is "fall".

four times higher in the Eastern Highlands $(\mathrm{B}=1.312$, $p<.05)$. Odd ratio values are 6.2 and 3.7 respectively.

For fights, children in the 3rd corrected quintile $(\mathrm{B}=1.371, p<.05)$ are four times more likely to be involved than children in the richest quintile. For quintile $4(\mathrm{~B}=1.257, p<.05)$, the risk is 3.5 . Odd ratio values are 3.9 and 3.5 respectively. Boys are twice as often involved in fights than girls $(\mathrm{B}=.640$, $p<.05$ ), odd ratio is 1.89 .

For road traffic accidents, children in the richest quintile $(\mathrm{B}=.562, p<.05)$, are much less exposed than children in the poorest quintile. The odd ratio is 1.75 .

Compared to children aged 12 to 14 , the younger children of $0-2$ years $(\mathrm{B}=-1.059, p<.05)$, are three times less exposed (odd ratio $=.347$ ) to road traffic accidents, and children of 9-11 years $(\mathrm{B}=.520$, $p<.05)$, are most exposed with an odd ratio of 1.68 .

For territorial planning areas, with the South being taken as a reference category, the risk of traffic accidents for a child is the lowest in the West Highlanders $(\mathrm{B}=-1.237, p<.05)$, followed by the
North Center $(\mathrm{B}=-1.163, p<.05)$, the East Highlands $(\mathrm{B}=-1.053, p<.05)$, the Northwest $(\mathrm{B}=$ -1.034, $p<.05)$, and Northeast $(\mathrm{B}=-.805, p<.05)$. Odd ratio values are respectively $.29, .313, .349, .356$, and .447 .

As for parental punishments, the results come as a surprise: The only Wald coefficient with a significance of .05 shows that boys $(\mathrm{B}=-1.048$, $p<.05)$ are three times less often punished than girls with an odd ratio of .350 .

\section{DISCUSSION}

At the end of this rapid overview of the available Algerian data on road traffic accidents, the authors can make the following observations:

(1) MICS4 is requiring work on data quality and construction of wealth score and quintiles;

(2) MICS4 is however a source of data that cannot be neglected;

(3) Finally, with regard to road accidents in children under 15, the MICS4-Algeria should be used for further research and critical scrutiny of data. 


\section{CONCLUSIONS}

The authors' hypothesis that children from richer parents are less exposed to road traffic accidents is partially confirmed but needs more refinements, in particular regarding the wealth score calculation.

More work is needed on the wealth score calculation as well as the wealth quintile. This crucial determinant of health related issues is ineffective as can be found in the UNICEF database.

\section{References}

Bourbeau, R. and C. Noël. 2000. "Demographic Projections for the Prevention of Road Accidents: The Example of Quebec, 1995-2016." Cahiers Québécois de Démographie 29(1):57.

Charbit, C. 1997. Human Factors in Traffic Accidents: A Major Potential for Preventive Action. Retrieved (https://www. fondation-maif.fr/fondation/resources/pdf/actions-preventio n_rf.pdf).

Cloutier, M.-S. 2008. Road Accidents Involving Pedestrian Children: Spatial Analysis of Potential Risks and Perceived Risks for Better Prevention. Retrieved (http://hdl.handle. net.proxy.bibliotheques.uqam.ca:2048/1866/6520).

INSP. 1992. "National Health Survey: Methodological Aspects,
Organization, Preliminary Results.” Issue 1, Algiers.

_. 2007. "National Health Survey: Epidemiological Transition and the Health Care System." Algiers.

MSPRH/ONS. 2008. "Monitoring of the Situation of Children and Women." National Multiple Indicator Survey.

MSPRH/UNICEF. 2015. "Monitoring of the Situation of Children and Women." Multiple Indicator Cluster Survey (MICS) 2012-2013 (Primary Report). Retrieved (http://hdl. handle.net.proxy.bibliotheques.uqam.ca:2048/1866/6520).

Peltier, J. 2012. "Impact and Prevention of Road Accidents Involving Large Wildlife on the Quebec Department of Transport Network." The Canadian Naturalist 136(2):89-94.

Richer, I. and J. Bergeron. 2007. "Relationship Between Cannabis Use and Hazardous Driving." Drugs, Health and Society 6(2):117-151.

Rutstein, S. O. and K. Johnson. 2004. The DHS Wealth Index. DHS Comparative Reports No. 6. Calverton, Maryland: ORC Macro.

\section{Bios}

Kouaouci Ali, Ph.D., professor of demography, University of Batna-1, Algeria; research fields: multivariate analysis, indirect estimation techniques, research methodology.

Khaldi Abdelkamel, Msc in demography, $\mathrm{PhD}$ student, University of Batna-1, Algeria; research field: road traffic accidents. 